
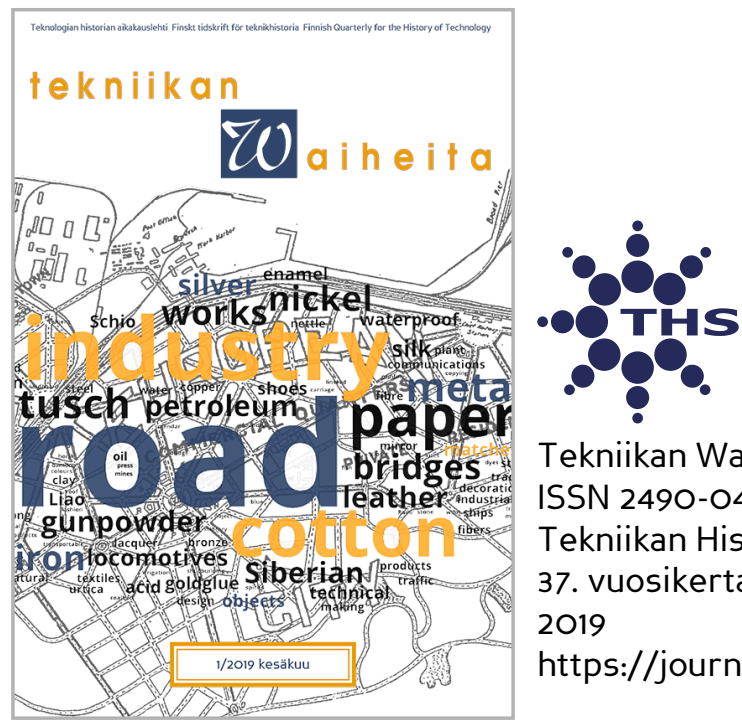

Tekniikan Waiheita

ISSN 2490-0443

Tekniikan Historian Seura ry.

37. vuosikerta:1

2019

https://journal.fi/tekniikanwaiheita

Lectio Preacursoria 19.1.2019: The Finlandisation of Shipbuilding Industrialisation, the State, and the Disintegration of a Cold War Shipbuilding System.

\title{
Saara Matala
}

(iD https://orcid.org/0000-0003-3571-1825

To cite this article: Saara Matala, "Lectio Preacursoria 19.1.2019: The Finlandisation of Shipbuilding - Industrialisation, the State, and the Disintegration of a Cold War Shipbuilding System," Tekniikan Waiheita 37, no. 1/2019): 58-65.

To link to this article: https://doi.org/10.33355/tw.83226 


\title{
Lectio Preacursoria 19.1.2019: The Finlandisation of Shipbuilding - Industrialisation, the State, and the Disintegration of a Cold War Shipbuilding System.
}

\author{
Saara Matala'
}

Saara Matalan teollistumisen historian väitöskirja tarkastettiin Aalto-yliopiston Insinööritieteiden korkeakoulussa 19.1.2019. Vastaväittäjänä toimi Richard Hirsh (Virginia Tech), ja kustoksena vieraileva professori Mats Fridlund. Väitöskirja on saatavilla elektronisena versiona Aalto-yliopiston julkaisuportaalissa (https://aaltodoc.aalto.fi/) ja luettavissa suoraan http://urn.fi/URN:ISBN:978-952-60-8388-9

Ärade Custos, honoured opponent, hyvät kuulijat, everyone.

Tämän tutkimusprojektin aikana Suomen telakkateollisuus on noussut toistuvasti lehtiotsikoihin. Mikä on Suomen laivanrakennuksen ja valtion suhde? Millaiseksi muodostuu kansallinen lainsäädäntö kansainvälisessä kilpailussa? Miten liikkuvat isot laivatilaukset ja niiden vaatimat isot rahat? Kenellä on halu, vastuu ja mahdollisuus vaikuttaa telakoiden kehitykseen?

On selvää, että teollisuus ei kehity tyhjiössä eikä passiivissa. Teollisuus kehittyy taloudellisessa, poliittisessa, ja kulttuurillisessa kontekstissaan. Teollisuutta kehittävät ihmiset, jotka tekevät päätöksiä saatavilla olevan informaation, odotusten ja kokemusten perusteella. Päätöksentekohetkellä on usein kiire, informaatio poikkeuksetta puutteellista.

Empiirisen historiantutkimuksen avulla on mahdollisuus ottaa askel taaksepäin ja arvioida päätösten perustoja, niiden pitkäaikaisia vaikutuksia sekä monimutkaisia riippuvuussuhteita, jotka tapahtumahetkellä olivat usein epäselviä.

Mikä oli Suomen laivanrakennuksen ja valtion suhde? Millaiseksi muodostui kansallinen lainsäädäntö kansainvälisessä kilpailussa? Kenellä oli halu, vastuu, ja mahdollisuus vaikuttaa teollisuuden kehitykseen?

Teollistumisen historia ei ole tuomioistuin, joka kertoo, kuka oli oikeassa ja kuka väärässä. Sen sijaan historiantutkimuksen metodit tarjoavat mahdollisuuden pureutua teollisuuden ja sen toimintaympäristön vuorovaikutukseen: Historiantutkimus tuo välineitä tietopohjaiseen keskusteluun teollisuuden muutoksesta ja menneisyyden perinnöstä siinä yhteiskunnassa, jossa nyt elämme.

The rest of this public examination is in English.

The period we know as the Cold War, from the late 1940s to the early 1990s, is best recalled as the era of superpower confrontation that brought up the development of militaryindustrial complexes. The key question in the history of Cold War science and technology is to what extent and how did the political context shape technological and industrial development: How did the politicization of technology, state interventions and available public financing instruments shape industrial development?

\footnotetext{
${ }^{1}$ Saara Matala on teknologian historian tutkija, Tekniikan Historian Seuran hallituksen jäsen ja Tekniikan Waiheita -lehden toimittaja.
} 
During the same period, the world shipbuilding experienced a rapid industrial expansion and a precipitous de-industrialisation in the aftermath of the 1970s oil crisis. The centre of gravity of the global shipbuilding was re-located from western Europe to the Far East. Only knowledge-intensive special-purpose vessels remained in Europe.

In most countries, including countries otherwise similar to Finland like Sweden, these trends had little to do with the Cold War, but international competition, rise of the Asian industrial giants, global over capacity, and economic cycles. However, the central questions in the maritime historiography are often similar than those in the Cold War history of technology: How did the politicisation of the labour-intensive technology industry, state interventions, and public financing instruments shape industrial transformation?

In my thesis, I studied the transformation of the Finnish shipbuilding industry in its political, economic, and cultural context of the Cold War Finland. In the international comparisons, the Finnish development appears extraordinary in two respects. The Finnish shipbuilding was down-scaled later and the Finnish shipyards specialised in special-purpose vessels earlier than the European average. Both contemporary and retrospective accounts argue that the Finnish distinct development was merely thanks to the extensive bilateral trade with the Soviet Union.

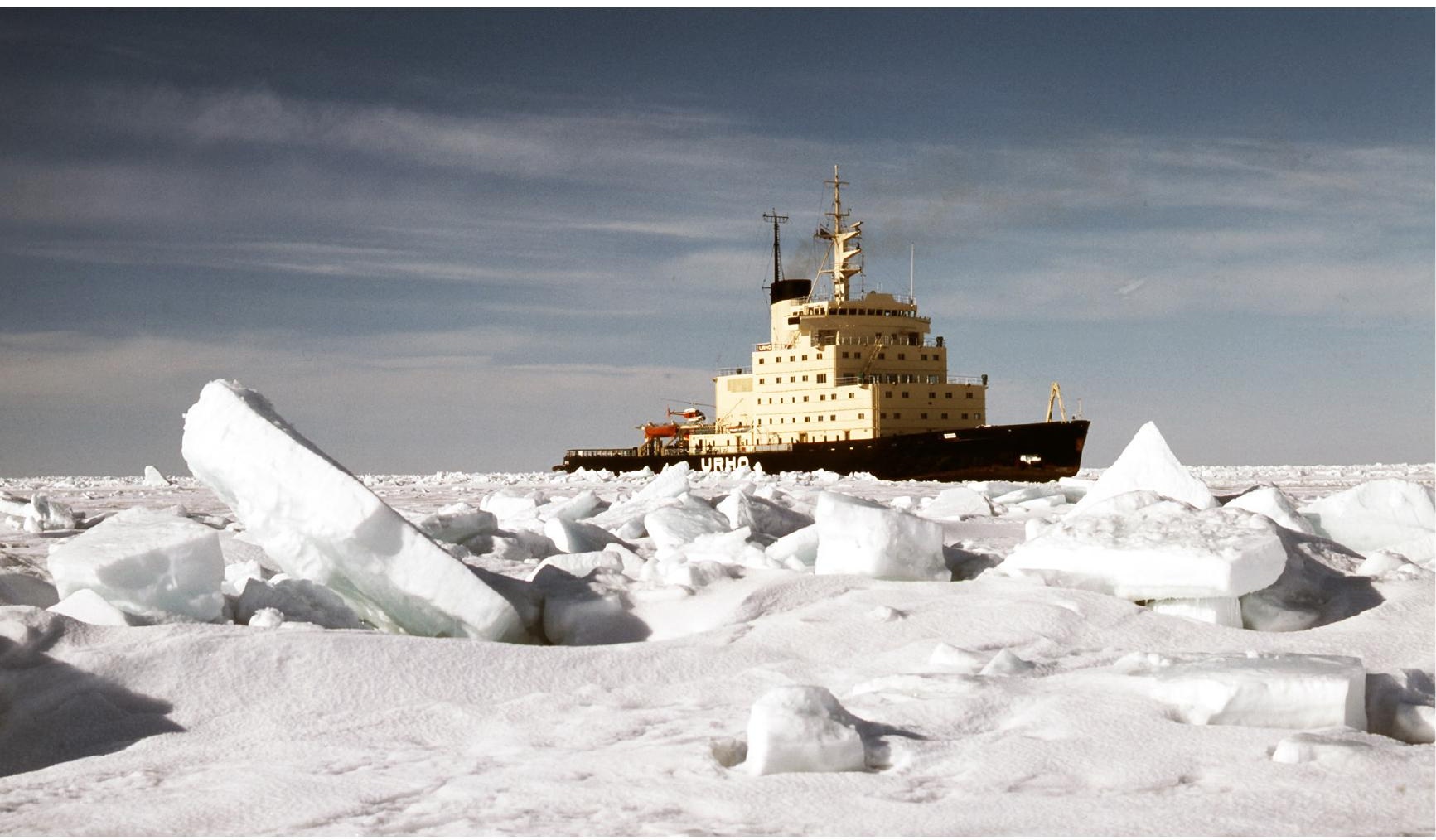

Icebreakers and President Urho Kekkonen depict the popular imaginary of Finnish shipbuilding. To put them to perspective, they need to be studied in their political, economic, and cultural context of the Cold War Finland. Photo: Aker Arctic Inc. 
The title of this thesis is from a British newspaper article that pondered the Finnish difference in 1984. Its title as well as its conclusions called attention to Finland's relationship with the Soviet Union. The article chimed in with the prevailing narratives on the Finnish Cold War shipbuilding that highlight the commitment of the high political actors, laugh at the irrational aspects of the Finnish-Soviet cooperation, credit the bilateral clearing trade and payment system as the guarantee of the stable, profitable, and continuous ship exports, blame the state from abandoning shipyards in their difficulties, and are convinced that Finland, unlike the rest of Europe, did not subsidy shipyards.

I chose to treat these established narratives as "national myths". Myths are not untrue but combinations of selected facts, personal recollections, and ideas. They are widely shared but rarely validated stories that communities tell to give meanings to their past.

Myths are important; they are essential for how nations and individuals understand their past and themselves; they carry information and propose certain ways of acting and thinking. However, in order to facilitate knowledge-based policy-making, or a meaningful discussion on the legacy of Cold War in Finland today, these myths need to be critically re-evaluated based on primary sources. They need to be put in perspective and under scrutiny.

The title, "Finlandisation of Shipbuilding" coins the hypothesis concerning the unique connection between the Cold War politics and the Finnish industrial development. It points out that there was something interesting there that differentiate Finland from the European counterparts: a special flavour that belonged to a particular historical place and era.

I chose not to use the vague and controversial actors' term Finlandisation as an analytical concept. Instead, I studied the Finnish shipbuilding industry as a "techno-economic system" and examined the "national style" the system expressed during the Cold War.

I defined the techno-economic system much in accordance with the theory of Large Technological Systems (LTS) as a heterogeneous, problem solving entity consisting of tangible and intangible, institutional and human components. The most visible parts of the Finnish techno-economic shipbuilding system were the shipbuilding companies and shipyards, but without the administrative, legislative, or human components that intermediated financing and contracts, gave information, or provided means of control and cooperation, no ship would have been built. Together, these various system components contributed to the goal which was profit-oriented shipbuilding. I call it a techno-economic system to underline that steel and money, technological and economic components, were equally important.

I analyse the dynamics within this techno-economic shipbuilding system, its relationship with the state, and its disintegration at the end of the period, by focussing on the national style. National style, defined by Thomas Hughes, consisted of processes, practices, and technologies that had established as ordinary within a certain system and gave it its distinct qualities.

According to the LTS theory, technological systems gain momentum and proceed towards a greater stability when they mature. Literature on system building has demonstrated how the political tensions and struggles that characterizes the early stages, diminish and the system may turn seemingly apolitical or even invisible.

It is challenging to study invisibly tensions and struggles. To tackle the problem, I chose to focus my study on the system disintegration instead of the more conventional approach of system building. The disintegration of the system re-politicised certain system compo- 
nents and the style that had been established in the mature system. In that way, the disintegration provided a methodological opportunity to reconsider the politics embedded in the mature system as well.

A focused study with a restricted number of factors can approach the research object from one angle. An approach illuminates some aspects of the Cold War techno-economic shipbuilding system while many other aspects remain in the shadows. In addition, empirical historical research is heavily reliant upon the availability of primary archival sources and the Finnish shipyard archives are very fragmented. Archiving practices have seldom been consistent and documents have been destroyed on purpose or by accident. Instead of one coherent chronological story, I chose to examine the system disintegration from five different perspectives: State-level technopolitics, technological cooperation, institutions of the bilateral trade, industrial reorganisation, and state financing. I chose these approaches in a way that enabled me to understand the messy interaction between the different, multilayered transformation processes and to re-evaluate the national myths of the Finnish Cold War shipbuilding.

First, I focused on the technopolitics of shipbuilding. Technopolitics means, as defined by Gabrielle Hecht, the strategic practice of using technology to enact political goals. In Finland, President Kekkonen has evolved into the personification of technopolitics and political commitment to the Finnish-Soviet trade. While the myriad entertaining stories of presidential fishing trips constitute a substantial part of the Finnish eastern trade folklore, scientific scrutiny reveals more relevant questions behind the presidential limelight. Indeed, a stateman promoting private business raises rather than put to rest questions of technopolitics. My analysis underlines the political agency of the industry, the institutional structures that enabled companies to mould their products into technopolitical instruments, and the motivation of the high political actors to accept these requests of assistance from the industry.

According to the study, Finland's status as a neutral country increased rather than decreased the politicisation of non-military technology during the Cold War. Technologically advanced but generally peaceful ships, such as icebreakers, provided the politicians with instruments to address critical questions related to national security, national prestige, and national welfare in international relations without endangering Finnish neutrality. Unlike in the Cold War literature typically, technology appears from this angle not as a tool of power but an instrument of negotiation.

Second approach to the Finnish shipbuilding system was the non-commercial scientifictechnical and industrial cooperation between Finland and the Soviet Union. My analysis highlights the Finnish agency in shaping the bilateral interaction. The institutions of cooperation in Finland came to mirror the ones in the centrally coordinated planning economy. They created an interface in a capitalist country to the Soviet economic planning. Even though these institutions were introduced by the Soviet Union as political tools, they were repurposed by the Finns to improve their corporate branding and competitive position. Joint techno-scientific projects were not without economic and technological motives, they sometimes had concrete and long-lasting consequences, but they were carried out as a performance of friendly cooperation.

Third, I concentrated on the bilateral clearing trade and payment system. Clearing denotes technical arrangements and practices to balance payments between Finland and the Soviet Union. Originally, it was practical rather than a political choice to enable high-volume 


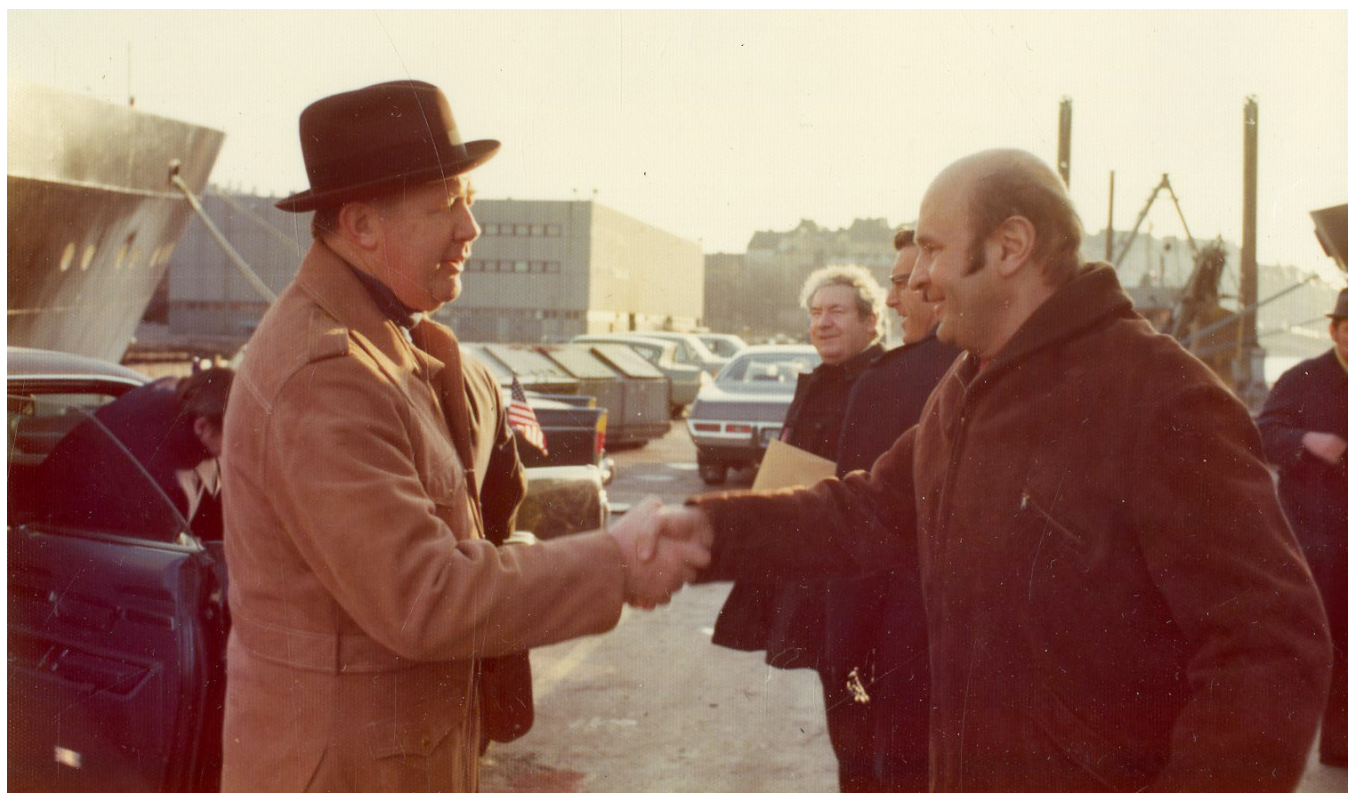

Technopolitics of shipbuilding was more than Presidential meetings: It was essentially about long-term transnational networking. US Ambassador to Finland Mark Austad visiting the Helsinki shipyard. Pictures: Mark Austad's collection, WSU Steward Library.

trade without convertible currencies. In the course of time, it evolved into the symbol of profitable, continuous, and stable ship export. The state-level clearing system translated the private ship contracts into state-level business and created a direct connection between ship trade and domestic employment, national energy supply, and monetary policy. The Finnish shipyards enjoyed the state-level bilateral trade system and related pre-payment arrangements without having to suffer from the restrictions of bilateralism. However, as my study shows, the benefits of clearing trade for the Finnish shipbuilding resulted not from the clearing system itself but from how the trade and payments were managed by the politicians and administration.

Fourth perspective to the Finnish techno-economic shipbuilding system was industrial reorganisation during the long 1980s. From this point of view, the last decade of the Cold War appears as a period when the shipbuilding system and the state tried to find a new balance between the domestic production capacity and Soviet demand for Finnish-built tonnage.

Financial sovereignty and the future prospects determined the negotiation position of the shipyards in relation to the state government. The bankruptcy of the biggest Finnish shipbuilding company in 1989 was a surprise for many. Yet, one cannot say that the shipyard crisis had arrived Finland unannounced. Since the late 1970s, the shipbuilding industry had tried to interpreted and address the new challenges and negotiate on state-support in several cooperation committees in public and in private. Nevertheless, the industrial reorganisations were eventually carried through not as results of strategic planning but as ad hoc decisions, accidents, and struggles. 
Finally, I examined Finnish ship financing policy. The Finnish Cold War shipbuilding was not free from state financing and support but the level was generally moderate and it often came in forms that were unrecognizable in the international comparisons. State subsidies and financing in western and domestic trade became topical as a response to growing problems in the Soviet trade only in the 1980s. The ability and willingness of Finland to continue along a distinct trajectory and to opt for unique mechanism diminished alongside the European integration proceeded. From this point of view, the shipyard financing became an arena for Finland to re-locate itself in the post-Cold War world. The role of state supporting national competence in the international business and integrating Europe remained but changed.

In all five cases, the system disintegration had started well before the dissolution of the Soviet Union and the end of the Cold War. The changes in Soviet economic priorities and the global price competition in shipbuilding were too great for the Finnish Cold War shipbuilding system to resist. However, a more interesting question than why the deindustrialisation in the Finnish shipbuilding capacity took place in the 1980s, is why it was delayed so long and why it was a surprise.

My results underline the role of experience and expectation in industrial decisionmaking. Most of the momentum that kept the Finnish Cold War shipbuilding system on its own trajectory, was connected to the Finnish-Soviet relationship. The Finnish Cold War shipbuilding system became integral in economic, political, and cultural aspects of

25. 10. 1989

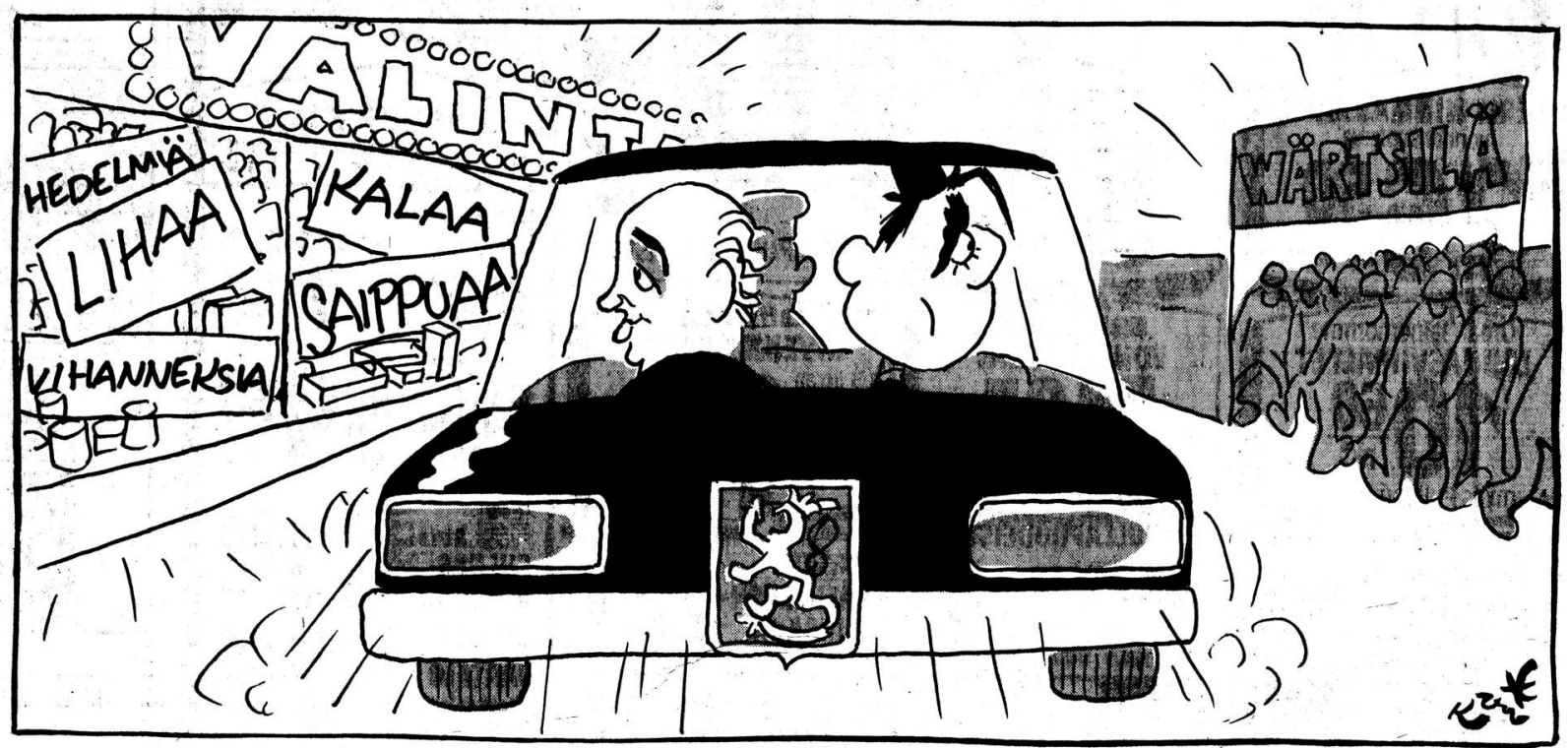

Kari, copyright 1989 by arrangement with Helsingin Sanomat

The disintegration of the Finnish-Soviet trade and the Finnish Cold War shipbuilding system were interconnected but different processes. Kari Suomalainen's interpretation of Mikhail Gorbachev's visit to Finland October 1989. Published HS. 25.10.1989, photo: Visavuori Museum, used with permission by Kari Suomalaisen perikunta. 
this peaceful co-existence between the two countries. The trust in the continuance of the state-level relationship added to the system momentum and helped it to resist changes even after the political and economic motives no longer gave it new impetus.

Trust is a positive thing that decreases transaction costs and increases predictability. However, we should not confuse the inertia of the Finnish-Soviet relationship with stability, and not mistake close connections with friendship. The Finnish-Soviet close relationship had its foundation in positive experience, institutional convenience, compatible interests, opportunism, and the lack of alternatives.

The "friendship" between the countries had too many tangible consequences to be understood as merely rhetorical. Yet, it was never a victory march but cold and broken. With the hindsight, shipbuilding in Finland without the special Soviet trade proved not to be unbearable but for a long, it was unimaginable.

How did the political context shape the industrial development in Finland?

The Cold War and the politicisation of technology and technology transfer introduced a novel set of restrictions and opportunities. Soviet Union was clearly important for the development of the Finnish Cold War shipbuilding system. However, Finnish shipbuilding industry developed as it did not because it was next to the Soviet Union but because it was in between the east and the west. It was the co-existence of three different markets - eastern market, western market, and domestic market - with their different production structures, financing arrangements and economic cycles, that provided counter cyclical effect, leverage in negotiations and occasional rescue boats in distress.

Finlandisation was not so much a concept than it was a question on the agency of a small country in the international order. As this study demonstrates, the Cold War was an era of international tensions, but the confrontations coexisted with convergence and transnational cooperation in which political, economic, and technical interests were overlapping.

The title, "Finlandisation of Shipbuilding," located this study in a certain geographical place and historical time: the Cold War Finland. It was not a statement nor a conclusion but a starting point of an historical inquire. It opened up a window to examine shipbuilding but also Finland and the legacy of the past in the society in which we are living today.

I ask you, honoured professor Richard Hirsh appointed as opponent by the School of Engineering, to present the observations that you consider appropriate for this dissertation. 